\title{
The Effect of Company Characteristics and Cooperate Social Responsibility on Company Financial Performance
}

\author{
Zahroh Z.A. $^{\mathrm{a}}$, Suhadak ${ }^{\mathrm{b}}$, Muhammad Saifi ${ }^{\mathrm{b}}$ and Nila Firdausi ${ }^{\mathrm{b}} *$ \\ ${ }^{a}$ Business Administration Doctoral Program, Faculty of Administrative Sciences, University of Brawijaya, Malang Indonesia \\ ${ }^{b}$ Faculty of Administration Science, University of Brawijaya
}

\section{ARTICLE INFORMATION}

\section{Article history:}

Data submission : 2 September 2019

$1^{\text {st }}$ revision: 12 December 2019

Accepted: 1 January 2020

Available online: 2 February 2020

Keywords: company characteristics, CSR, company's financial performance

\section{ABSTRACT}

\begin{abstract}
Increased intense global competition has made CSR as a topic that must be considered by business people, especially for companies that carry out activities related to natural resources. The rationality for this statement is that CSR has become one of the company's responsibilities to stakeholders, and company characteristics are an inherent risk inherent in the company. All of this is related to the company's financial performance. Various previous studies have been conducted to discuss the effect of company characteristics and CSR on company financial performance, but give different results. The purpose of this study was to obtain empirical evidence of the influence of company characteristics and CSR on the financial performance of companies listed on the Indonesia Stock Exchange (BEI) in 2012-2016. The study population was natural resource companies listed on the BEI 2012-2016 of 43 companies, with through specific criteria obtained a sample of 32 companies. The results showed that company characteristics significantly influence the company's financial performance as well as CSR significantly influence the company's financial performance.
\end{abstract}

2020 FIA UB. All rights reserved.

\section{Introduction}

The issue of CSR has been rife in various parts of the world, and various studies have been carried out relating to CSR, but it gives different results. Bhutta and Hasan (2013) and Kamasak (2017) have proved the influence of company characteristics on profitability empirically. Bhuta and Hasan (2013) with a sample of food companies listed on the Karachi stock exchange, found a negative effect between company characteristics and profitability. In contrast to Bhutta and Hasan, Kamasak (2017) found a positive effect between characteristics and probability. The study examines the effect of company characteristics on profitability based on growth theory. Companies that have high growth potential provide benefits because the investment is expected to provide high returns in the future. The company's growth opportunities projected with various combinations of investment opportunity sets (IOS) (Hossain et al., 2000). The higher the company's growth rate, the greater the company's ability to provide high profitability, in this case, the company's financial performance. The improved growth in the company's financial performance is considered to have a better prospect.

Factors of company characteristics can influence the company's goal to increase profitability, and its effect can saw through Corporate Social Responsibility (CSR). Chen and Wang (2012) have proved the effect of CSR on profitability empirically. They found a positive influence between CSR and profitability. In contrast, Bhustan and Gurau (2013) found a negative influence between CSR and profitability. This research is a development from previous research that discusses, analyzes, and develops the main concepts and concludes the influence of company characteristics and CSR on the company's financial performance.

\section{Theory}

Company characteristics are factors that are special and innate to the company. Some proxies of company characteristics used in this study are (a) Company size. Company size is a variable that is widely used to explain the differences in disclosures in a company's annual report. The measurement used for size is total assets 
(Benkreaiem and Gurau, 2013). (b) Growth (Growth). Company growth is a condition that grows, progresses, or develops. The company's growth opportunities can be projected with various combinations of investment opportunity sets (IOS) (Hossain et al., 2000). Measurement of growth can be done by looking at sales growth (Benkreaiem and Gurau, 2013). (c) Asset structure is the ratio that describes the fixed assets owned by the company with the total assets of the company (Omran and Pointon, 2009).

Corporate social responsibility (CSR). One of the company's responsibilities to stakeholders is in the form of CSR. The influence of CSR on corporate financial performance based on signaling theory. The meaning of signaling is the company's condition based on the perspective of people outside the company. Analysts will further analyze signals from companies before investors decide to sell or buy company stock. If there is a positive signal, investors will be interested in buying the company's shares so that the market value rises.

Conversely, if there is negative information, investors will choose to release shares of a company (Bhusan, 1989). This signaling means that the higher the CSR, the higher the profitability. The lingkage happens because CSR is very dependent on the profits of the company, and vice versa. It is measured using the CSR Dislousures Items (CSRI) checklist. CSRI is a disclosure made by a company in fulfilling its responsibilities in the economic, environmental, and social fields without prejudice to the interests of investors. The disclosure guided by the Global Reporting Initiative (GRI) (Bhustan and Hasan, 2013).

The company's financial performance is the main goal to be achieved by all companies to obtain maximum profit. This condition happens because the sustainability of a company depends on its ability to generate profits. One of the evaluations of financial performance through profitability as a measurement used Return of Assets (ROA), Return on Equity (ROE) and Net Profit Margin (NPM).

The hypothesis of this research is

H1: The characteristics of the company affect the company's financial performance

$\mathrm{H} 2$ : CSR affects the company's financial performance

\section{Research Method}

The type of data used in this study is secondary timeseries data. Secondary time-series data are data collected in chronological order and obtained from the Indonesia Stock Exchange (IDX). The study population is allnatural resource companies on the Indonesia Stock Exchange for the period 2012-2016 as many as 43 companies. The sampling method used in this study was purposive sampling, that is, samples taken from populations that met the criteria obtained a sample of 32 companies. Table 1 describes variables used in this study.
Table 1. Variables, indicators and formula

\begin{tabular}{|c|c|c|c|}
\hline Variables & Indicators & Notation & Formula \\
\hline \multirow{3}{*}{$\begin{array}{l}\text { Company } \\
\text { Characteristi } \\
\text { cs (X1) }\end{array}$} & Size & $\mathrm{X}_{1.1}$ & $\mathrm{~S}=\mathrm{Ln}$ (Total assets) \\
\hline & $\begin{array}{l}\text { Growth } \\
\text { sales }\end{array}$ & $\mathrm{X}_{1.2}$ & $\mathrm{G}=\frac{\text { Sale } \mathrm{t}-(\text { Salet-1) }}{\text { Salet }}$ \\
\hline & $\begin{array}{l}\text { Assets } \\
\text { Structure }\end{array}$ & $\mathrm{X}_{1.3}$ & $\begin{array}{l}\mathrm{SA}= \\
\frac{\text { Amount of fixed Assets }}{\text { Total Assets }}\end{array}$ \\
\hline CSR (X2) & CSR & $\mathrm{X}_{2.1}$ & $\operatorname{CSRIj}=\frac{\Sigma x_{i j}}{N j}$ \\
\hline \multirow{3}{*}{$\begin{array}{l}\text { Company's } \\
\text { Financial } \\
\text { Performance } \\
\text { (Y2) }\end{array}$} & ROA & $\mathrm{Y}_{2.1}$ & $\begin{array}{l}\text { ROA = } \\
\text { net profit after tas }\end{array}$ \\
\hline & ROE & $\mathrm{Y}_{2.2}$ & $\begin{array}{l}\text { Total assets } \\
\text { ROE = } \\
\text { net profit after tas }\end{array}$ \\
\hline & NPM & $\mathrm{Y}_{2.3}$ & $\mathrm{NPM}=\frac{\text { net profit }}{\text { sale }}$ \\
\hline
\end{tabular}

\section{Research Method}

Data analysis methods used include financial ratio analysis, descriptive statistical analysis, and inferential statistical analysis. Inferential statistical analysis in this study used the Warp-PLS analysis. Warp-PLS is used based on the research concept model as a multiinfluence and tiered influence. Besides, the variables analyzed in this study are latent with a formative indicator model. The model of influence between variables in this study, described by the following equation:

$$
\begin{aligned}
& Y_{1}=a_{1}+b_{1} X_{1}+b_{2} X_{2}+e_{1} \\
& \text { Where: } \\
& \mathrm{X}_{1} \quad: \text { Company's Characteristic } \\
& \mathrm{X}_{2}: \text { Corporate Social Responcibility } \\
& \mathrm{Y}_{1} \quad: \text { Company's Financial performance }
\end{aligned}
$$

\begin{tabular}{|c|c|c|}
\hline Indicators & weight & $p$ value \\
\hline Company Characteristics Variable & & \\
\hline Size & -0.702 & $<0.001$ \\
\hline Growth & 0.486 & $<0.001$ \\
\hline Assets Structure & 0.371 & $<0.001$ \\
\hline $\begin{array}{l}\text { Corporate Social Responsibility } \\
\text { Variable }\end{array}$ & & \\
\hline CSR & 1,000 & $<0.001$ \\
\hline $\begin{array}{l}\text { ROA } \\
\text { Company's Financial Performance } \\
\text { Variable }\end{array}$ & 0,557 & $<0.001$ \\
\hline ROA & 0,557 & $<0.001$ \\
\hline ROE & 0,278 & $<0.001$ \\
\hline NPM & 0,458 & $<0.001$ \\
\hline
\end{tabular}

Table 2. Indicator weight for company characteristics variable, corporate social responsibility and company's financial performance 
Exploration of Loading and Weights Indicator. Factor weight values illustrate the strengths and weaknesses of the indicators (dimensions) as a variable gauge. Dimensions (indicators) with large factor weight values indicate these dimensions (indicators) have a strong ability to reflect variables. The dimension (indicator) with the most significant factor weight value is the most robust (dominant) as a measure of the relevant variable. Positive or negative signs indicate the direction, as found in the path coefficient (regression).

Table 2 shows that all indicators of company characteristics are significant. Growth of company growth is a stronger indicator (dominant) as forming variables of company characteristics. CSR variables are only proxy by one indicator. Corporate financial performance variables, all significant indicators where ROA is a stronger indicator as forming the company's financial performance

\section{Results}

Hypothesis testing carried out by using Warp-PLS analysis. The results of hypothesis testing showed in Figure 1.

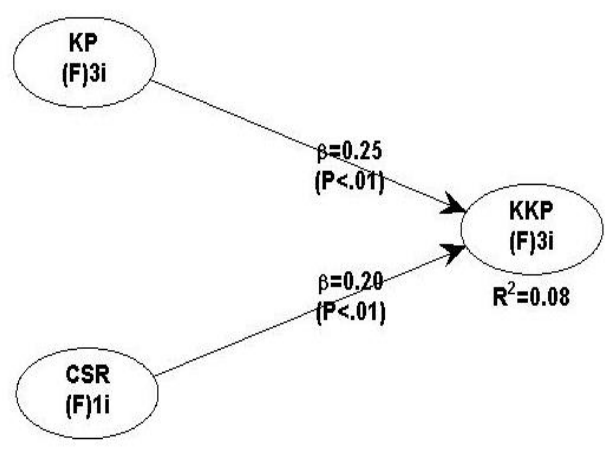

Figure 1. SEM results

Table 3. The results of hypothesis testing

\begin{tabular}{lll}
\hline \multicolumn{2}{c}{ Influence between Variables } & $\begin{array}{c}\text { path } \\
\text { coefficient }\end{array}$ \\
\cline { 1 - 2 } $\begin{array}{c}\text { Independent } \\
\text { Variables }\end{array}$ & \multicolumn{1}{c}{ Dependent Variables } & $0.253^{* * *}$ \\
\hline $\begin{array}{l}\text { Company } \\
\text { characteristic }\end{array}$ & $\begin{array}{l}\text { Company's financial } \\
\text { performance }\end{array}$ & $0.205^{* * *}$ \\
CSR & $\begin{array}{l}\text { Company's financial } \\
\text { performance }\end{array}$ & \\
\hline
\end{tabular}

\section{Discussion and Conclusion}

Hypothesis 1 states that company characteristics influence the company's financial performance. The results of the analysis of the influence of company characteristics on the company's financial performance showed that a path coefficient of 0.253 and p-value of $<0.001$ obtained. With a p-value $<0.01$, it can be concluded that the results are very significant, and the hypothesis is accepted. The path coefficient marked positive indicates that the better the characteristics of the company will result in a higher financial performance of the company.
The findings of this study do not support the research of Bhutta and Hasan (2013). The results show that the company's characteristics, as measured by growth, have not a significant positive effect on profitability. However, this study supports research conducted by Kamasak (2017). Kamasak's research shows that company characteristics have a significant positive effect on profitability. The results of this study also support the investment opportunity set from the research of Hossain et al. (2002), which states that companies with high growth potential provide high corporate profits as well. So that the higher the characteristics of the company, the higher the company's financial performance.

Hypothesis 2 states that CSR influences the company's financial performance. The analysis result of the influence of CSR on the company's financial performance obtained path coefficient of 0.205 and pvalue $=0.004$. With a $\mathrm{p}$-value $<0.01$, it concluded to be very significant, and the hypothesis is accepted. A positive coefficient indicates that better CSR will lead to an increase in the company's financial performance.

Li Sun's research results (2012) show that CSR has a positive effect on the company's financial performance. However, the results of this study do not support the research of Omran and Pointon (2012), which shows that CSR does not affect the company's financial performance. The results of this study support the Gover and Gover signaling theory (1993), which defines the condition of the company based on the perspective of people outside the company. These signals will further be analyzed by the analysis before deciding so that high CSR will have an impact on the company's image will be a positive signal that affects improving the company's financial performance.

\section{References}

Benkreaiem, R. \& Gurau, C. (2013). How do corporate characteristic affect capital structure decisions of French SMES: International Journal of Entrepreneurial Behavior \& Research, 19(2) 149164.

Bhustan. R. (1989). Firm characteristics and analyst following. Journal of Accounting and Economics, 1(1) 255-274.

Bhutta, N.T. \& Hasan, A. (2013). Impact of firm specific factors on profitability of firm on food sector, Open journal of Accounting, 1(2)19-25.

Chen, H. \& Wang, X. (2011). Corporate social responsibility and corporate finance performance in China: an Empirical Research from Chinese Firm, 11(4) 361-370.

Gover, J.J. \& Gover, K.M. (1993). Additional evidence on the association between the investment opportunity set and corporate financing, dividend and compensation policies, Journal of Accounting and Economics 16 (1)125-160.

Hossain, M., Cahan S. F. \& Adams N.B. (2002), The voluntary use of outside directors: New Zealand evidence, Journal of Accounting and Business Research, 30(4) 263-273.

Omran, M.M. \& Pointon, J. (2009). Capital structure and firm characteristic: An empirical analysis from Egypt, Review of Accounting and Finance 
$8(4) 454-474$.

Sun, L. (2012). Further evidence on the association between corporate social responsibility and finance performance: International Journal of Law and Management, 54(6) 472-484. 